\title{
Late Tertiary to Quaternary Tectonics of Irian Jaya
}

\author{
by D.B. Dow and R. Sukamto
}

Between 1978 and 1982 a team of Australian and Indonesian geologists carried out a major mapping project in hitherto geologically unknown parts of lrian Jaya in westernmost indonesia. This article describes the field techniques used and summarizes the scientific results, including the recognition of the Melanesian Orogeny, which began in the latest Miocene and continues today. This involves contemporary underthrusting of the Australian continent by the Pacific Plate - a process that is expressed on the surface by shale diapirism, mud volcanoes and active faulting.

\section{Introduction}

Until recently Irian Jaya, the Indonesian province covering the western half of the Island of New Guinea (Fig. 1), was one of the least explored regions in the world. The main reason for this is the very difficult access posed by the wide fringe of jungle-covered swamps and plains, and farther inland by the rugged mountains of the Central Range, where the bulk of the population lives.

By the early 1960s, most of the country with hydrocarbon potential had been geologically mapped by oil companies (Visser and Hermes, 1962), but the mountainous hinterland was still mostly unknown. A contributing factor has been a lack of reliable maps: over large areas the available topographic sheets are wildly inaccurate. A great advance was made when airphotos at 1:100,000 scale were acquired by a defence cooperation project between the Indonesian and Australian governments, and, although large areas in the east are usually covered in cloud and were therefore not photographed, cloud-free LANDSAT imagery is available for many of these gaps.

By 1978 arrangements were finalized between the Indonesian and Australian governments to undertake a geological survey of Irian Jaya as part of Australia's bilateral aid program under the auspices of the Australian Development Assistance Bureau. This project was a great challenge to our team of geologists from the Indonesian Geological Research and Development Centre (GRDC) and the Australian Bureau of Mineral Resources (BMR) when in 1978 we commenced work in the western extremity of the island, the Bird's Head region.

The geology of the Mesozoic and Tertiary sedimentary basins overlying the Australian continental crust in Irian Jaya was by then well known, especially in the west where commercial oil deposits had been found. The nature of the deformed northern margin of the crust was, however, an almost complete mystery. The great potential of this region for mineral deposits was demonstrated as early as 1936 by the chance discovery of the Ertsberg copper-gold deposits by a
Dutch team (Dozy, 1938) during an attempt to climb the highest mountain in Irian Jaya, now named Puncak Jaya. The mine developed here has since proved to be one of the richest major lodes in the world, though because of its extraordinarily remote locality at an elevation of over $3,000 \mathrm{~m}$, directly below the icecap of Puncak Jaya, its cost structure is also one of the highest in the world.

Unfortunately our work had to be suspended for security reasons in 1982, by which time only the western half of the province had been mapped at 1:250,000. However, we have been able to compile a reasonably reliable geological map at $1: 1,000,000$ scale of the whole region including the eastern half of the province. This was possible because the $1: 100,000$ airphotos, in combination with the LANDSAT imagery, show the major features of the geology remarkably well. The results of widely spaced traverse done during oil exploration (Visser and Hermes, 1962) were also helpful.

Working in Irian Jaya

Except for small networks around the few coastal towns, there are no roads in Irian Jaya, so ground travel is invariably difficult. Access to the jungle-covered swamps and plains is generally limited to meandering rivers, and these are impassable as soon as the hinterland mountains are reached. Thus the only practicable way to gain access to the mountains is to fly by light aireraft to the many small airstrips serving local administrative centres and church missions. From here one must walk, and in the populated highlands there is a network of tracks which allow reasonable, if arduous, travel. However, where the mountainous

Figure 1: Locality map. The island of New Guinea is traditionally likened to a bird with a head, body and tail.

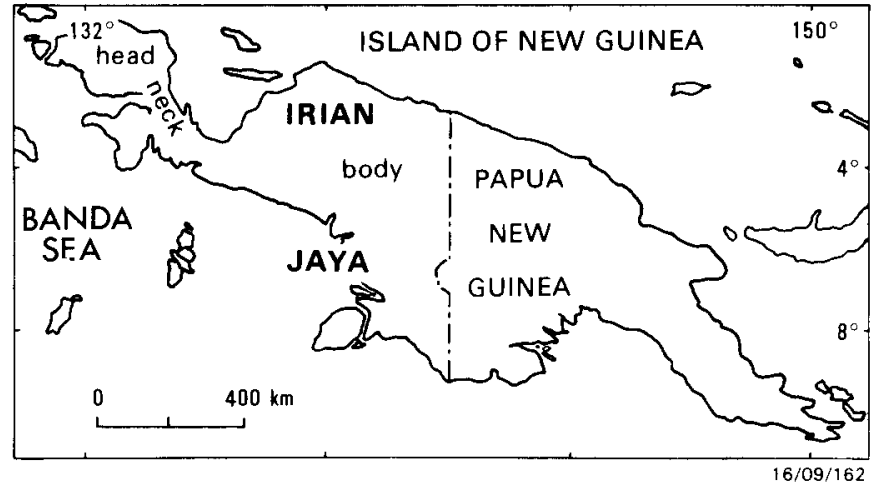




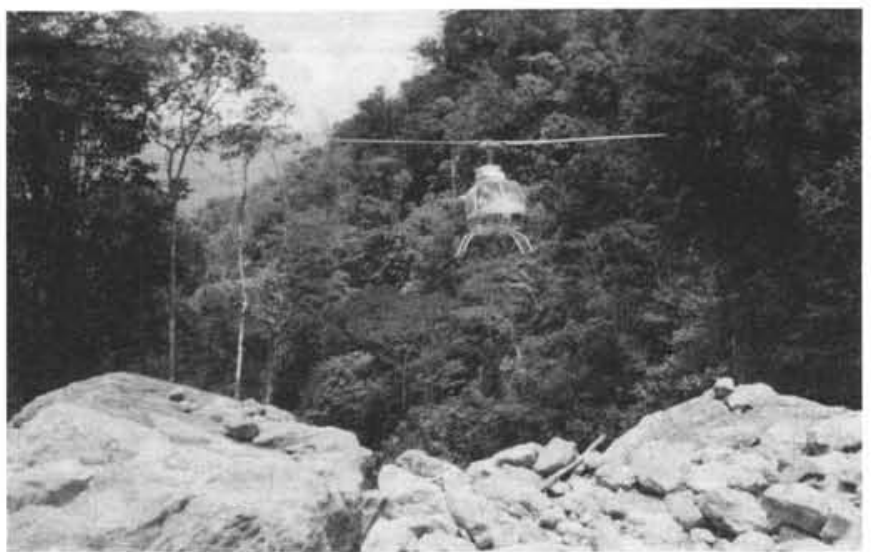

Figure 2: A difficult landing site. The helicopter made a one-skid landing using the large boulder on the left.

country is unpopulated or has only a few semi-nomadic tribes, walking tracks are almost non-existent, and travel by foot is extremely difficult and time consuming.

To overcome these obstacles the project adopted traverse techniaues used successfully by BMR during the mapping of adjoining Papua New Guinea in the preceding decade, using lightly laden, mobile, parties positioned by helicopters (Fig. 2). The groups, each consisting of one or two geologists and three to five porters, then followed predetermined routes, generally following rivers or streams, on traverses that occupied three to seven days. However, in areas devoid of helicopter landing sites, treks up to 10 days duration were often needed. In these latter areas it was usually necessary at the end of a traverse to cut helicopter landing pads out of the jungle, a task that can take up to a day and a half of very hard work. At the end of one traverse the party returned to camp to record the observations and prepare for the next one.

The work was certainly no pienic and the field work would not have been possible without the cooperation of the local inhabitants (Fig. 3) who acted as guides and porters and shared all the difficulties and hardships with fortitude and good humour. It is also a tribute to the stamina and competence of the team members - and the helicopter pilots - that four field seasons were carried out without serious illness or accident. Although our main aim of mapping the Central Range and finding new mineral deposits was not achieved, the geological results of the mapping have thrown much new light on one of the few convergent plate boundaries exposed on land.

\section{The Major Plate Movements}

The present form of Irian Jaya has been shaped very recently by profound earth movements that started in the latest Miocene and continue to the present day. This Melanesian Orogeny (Dow and Sukamto, 1984) is the result of convergence between the Pacific and Australian plates. The crustal adjustment involved has been extraordinarily complex and involved the interaction of many small crustal fragments. However, the geometry of the major structures, all of which are compressional, indicates that the convergence is roughly to the southwest (Dow and Sukamto, ibid). This direction corresponds closely with that postulated by Minster and Jordan (1978; see also AAPG, 1981). There is no evidence that the direction has changed markedly since the beginning of the Melanesian Orogeny. On the contrary, the major structures are best explained by a more or less consistent convergence in a $555^{\circ} \mathrm{W}$ direction.

The magnitude of the convergence, however, is not known, but the crustal shortening since the Early Pleistocene has probably exceeded $100 \mathrm{~km}$. This accords well with the figure of $125 \mathrm{~km}$ convergence obtained by extrapolating the postulated present-day rate of $12.6 \mathrm{~cm}$ per year (AAPG, 1981) back in time to the Middle Pleistocene.

\section{Main Crustal Elements}

The southern plains and swamps of Irian Jaya and most of the Bird's Head are underlain by stable Australian continental crust (Fig. 4), whereas the north coast marks the southern limit of similarly little-deformed oceanic crust of the Pacific Plate. The intervening belt of deformation, which makes up most of the body of the bird, is the westerly extension of the New Guinea Mobile Belt of Dow (1977).

Though it is mostly covered by sea, the composition of the Pacific Plate here is known from outcrops on the north coast and on the outlying islands. These rocks are all remarkably similar in mineralogy and represent the western continuation of the Oceanic Crust and Island Ares province of Papua New Guinea (Dow, 1977). They consist of pervasively altered, basic to intermediate island-are voleanics and subordinate oceanic basalts of Upper Cretaceous and Palaeogene age. Throughout the provinee, the island-are volcanics are overlain by Middle Miocene reef limestone (in places with late Lower Miocene at the base) and marl and younger clastic sediments. Ultramafic rocks are exposed along major zones of dislocation but are not extensive.

The Australian continental rocks consist of a basement of mainly fine-grained, highly indurated, and in places highly sheared, Palaeozoic sedimentary rocks. These are overlain by shelf sediments from 6 to $8 \mathrm{~km}$ thick, ranging in age from late Palaeozoic to mid-Tertiary. The Mesozoic rocks are mainly clastic sediments, whereas those of Tertiary age are almost exclusively shelf limestone.

The boundary between the New Guinea Mobile Belt and the Pacific Plate is a complex fault zone of great magnitude (Fig. 4). In the west this is called the Sorong Fault Zone, with proven left lateral displacement of over $350 \mathrm{~km}$. To the east this fault is offset to the south and succeeded by the Yapen Fault Zone, which because it is covered by the sea or recent alluvium is not well known. Farther east again the fault zone is also offset to the south and continues into Papua New Guinea as the Bewani-Torricelli Fault System of Hutchison and Norvick (1982, unpublished). Focal plane solutions (Ripper, 1975) indicate that this system is also predominantly left lateral.

Figure 3: Indonesian geologist questioning villagers high on the northern slopes of the Central Range.

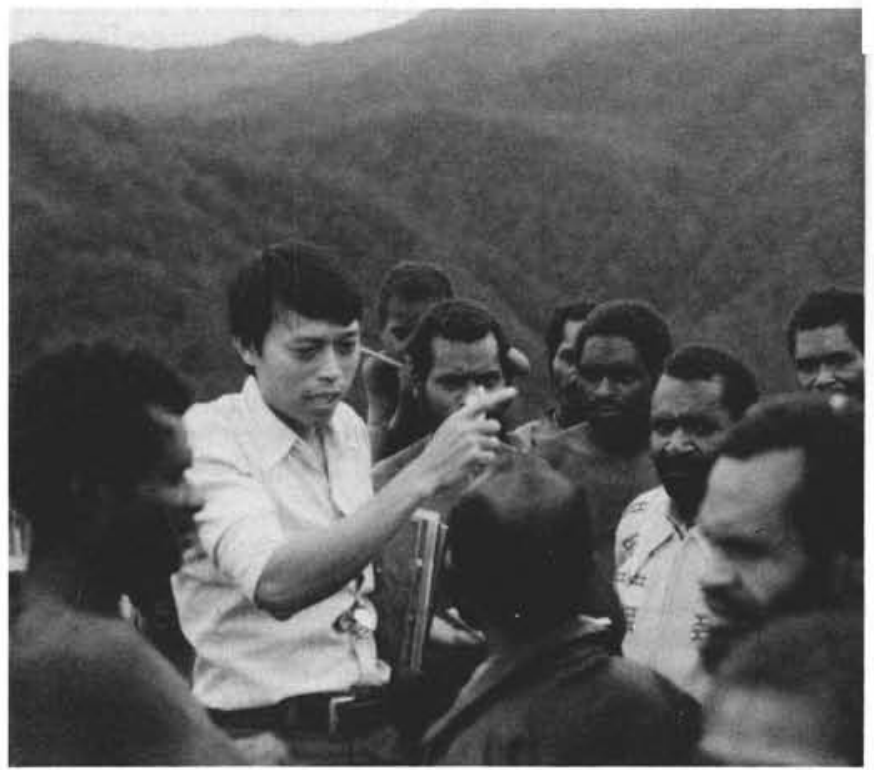


The most striking feature of the geology of Irian Jaya is the Bird's Head, a great salient of undeformed continental crust that protrudes northwards into the Pacific Plate. The major structures outlining this anomalous salient were produced during the Melanesian Orogeny, but the mechanism by which they formed is not known. Most authors have ascribed the formation to clockwise rotation or northwards translation, by as much as several hundred kilometres, of a fragment of Australian continental crust (Hamilton, 1979; Hermes, 1968; Norvick, 1979; Robinson and Ratman, 1978; Visser and Hermes, 1962). Recently, however, Pigram et al. (1982) and Pigram and Panggabean (1983) proposed that the Rird's Head region constitutes a separate microcontinent that has been rafted many hundreds of kilometres to its present position.

In light of the results of the recent mapping, we have proposed that the Bird's Head owes its protrusion to a greater crustal shortening in the body region (Dow

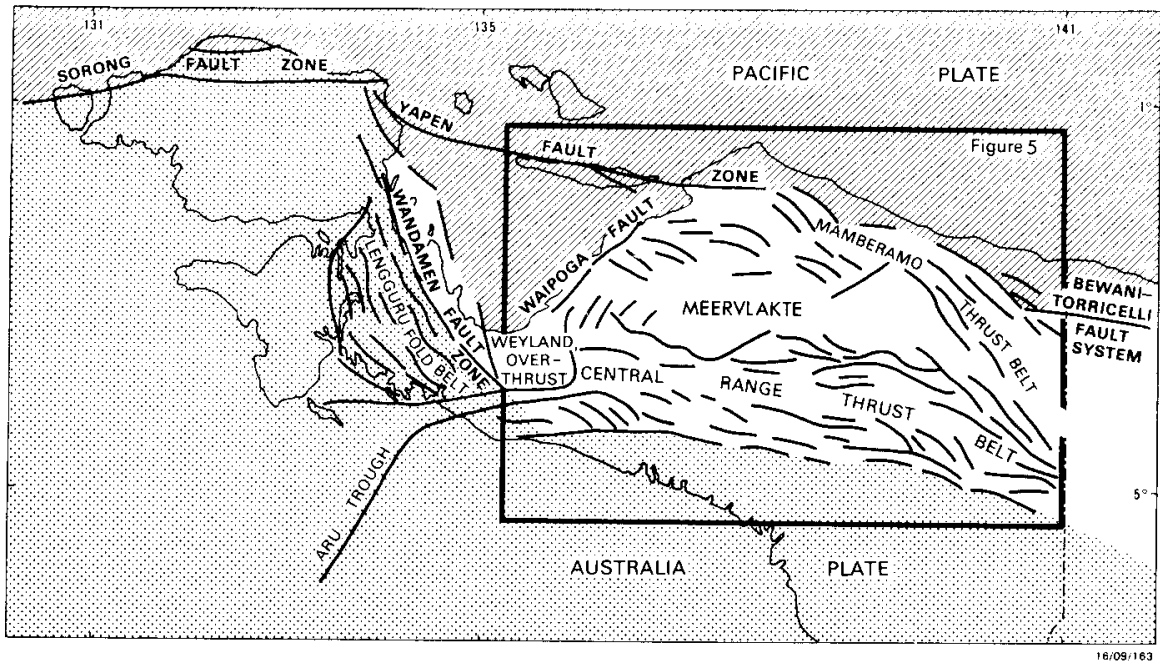
and Sukamto, 1984). Here the shortening, which probably exceeded $200 \mathrm{~km}$ since the start of the Melanesian Orogeny, has been accommodated entirely within the New Cuinea Mobile Relt by compressional deformation of the continental crustal rocks and by complex over and under-thrusting of oceanic crust and mantle of the Pacif ic Plate.

According to our hypothesis, the Bird's Head has reacted as a stable buttress, and as the Pacific Plate has encroached southwards in the body region the continental crust of the Bird's Head has protruded northwards into the westerly moving Pacific Plate. The differential displacement has been taken up along the $W$ andamen Fault Zone by a combination of overthrusting and right lateral strike-slip displacement.

There are, however, problems with both hypotheses. The rotation hypothesis does not explain why the continental fragement has moved against the relative southwesterly drift of the Pacific Plate. On the other hand, our hypothesis requires the crust underlying the Banda Sea to have provided a buttress that has prevented the apparently vulnerable Bird's Head region from being carried southwestwards. Most authors consider the Banda Sea crust to be oceanic and, therefore, not able to withstand the southward motion, but recent reports that rocks of continental origin have been dredged from widespread localities in the north Banda Sea (Prasetyo, 1983, unpublished) suggest that the sea may be largely underlain by continental crust which could possibly have acted as a buttress.

Whatever its origin, the protrusion of the Bird's Head into the westwards-moving Pacific Plate has exposed the northern extremity to huge stess, and the continental crust has reacted by the tearing-off of large crustal fragments, which have been carried westwards by the Pacific Plate. Middle Miocene acid volcanic rocks on the northwestern extremity of the Bird's Head have been of set by this means at least 370 $\mathrm{km}$ along the Sorong Fault Zone (Dow and Sukamto, 1984).

\section{New Guinea Mobile Belt}

The eastern half of Irian Jaya is dominated by two contrasting major physiographic features: The Central Range that forms the mountain backbone, and the remarkable lake plain (Meervlakte) to the north that channels most of the drainage from the northern half of the body. The Central Range, which exceeds $4,000 \mathrm{~m}$ elevation over most of its length and which culminates in the ice-capped Puncak Jaya at over $5,000 \mathrm{~m}$, was formed early in the Melanesian Orogeny

Figure 4: Main structural elements of Irian Jaya. New Guinea Mobile Belt unstippled.

by southwards overthrusting of the rocks of the northern margin of the Australian continental block. The Meervlakte on the other hand is one of the spectacular manifestations of underthrusting of Pacific Plate crust that started in the early Pleistocene and continues to the present day.

These, and all the other structures resulting from the plate convergence during the Melanesian Orogeny, are the western continuation of the New Guinea Mobile Belt in Papua New Guinea. Not surprisingly, the rocks exposed along the southern third of the Belt are of continental origin, while the northern two-thirds appear to be almost entirely of oceanic or island-arc affinities.

\section{Deformed Northern Margin of the Australian Plate}

The strongly deformed, continental crustal lithologies of the Central Range Thrust Belt form a zone $100 \mathrm{~km}$ wide (Fig. 5). These rocks, which involved the Palaeozoic basement and the overlying late Palaeozoic to mid-Tertiary shelf sediments, are overthrust to the south and in many places are tightly folded. The uppermost unit of the shelf succession over much of the Central Range is the New Guinea Limestone, which averages about $2,000 \mathrm{~m}$ in thickness and provides an invaluable stratigraphic horizon for unravelling the structure.

The northernmost fringe of the deformed continental crust is made up of Mesozoic and early Tertiary fine-grained clastics and intercalated marine volcanics, with a total thickness of over $10,000 \mathrm{~m}$. These were laid down on the northern continental slope and rise, and have been tightly folded by several deformations and regionally metamorphosed to the greenschist facies. Similar rocks in the easterly extension of this metamorphic zone in Papua New Guinea were metamorphosed during an island arc/continent collision in the Oligocene (Dow, 1977; Jacques and Robinson, 1977), so it is probable that the Irian Jaya rocks were metamorphosed at the same time. Nevertheless, on the evidence available to date, the metamorphics could conceivably have been formed during the Melanesian Orogeny.

It is important to note that if the metamorphism was Oligocene in age, the collision did not affect the shelf sediments making up the Central Range, for these, like their correlatives in Papua New Guinea, were laid down, essentially without interruption, until the Middle Miocene. 
the base of the lithosphere of hot low-density mantle material, by isostatic compensation and by other factors. These vertical movements are responsible for the block structural pattern of the continental and oceanic crusts (Artyushkov et al., 1979). Many data on these and horizontal movements come from geodetic analyses on the ground and from satellites (Bulanzhe, 1981).

Advances in seismology have had a marked bearing on the field of tectonics (Fig. 4). Extensive data on seismic events within the U.S.S.R. and elsewhere have demonstrated a link between earthquake sources and zones of active deep faults. The expansion of seismic networks and geophysical polygons set up in active seismic areas of the country has permitted seismologists to work out a rather successful technique for long-term earthquake prediction, which has already been verified in a number of cases (Anon. 1982). A medium to short-term earthquake prediction technique is now being developed, based on types of movements along the deep faults.

\section{Metallogeny}

One of the important achievements of Soviet geoscience is the recognition of certain regular patterns in the formation and distribution of minerals (Shcheglov, 1980; see also Smirnov, and Rundquist, this issue of Episodes - Ed.). Formational analysis applied to metallogeny makes it possible to identify metalliferous associations (formations), and to determine the location of mineral deposits within these associations. This popular new approach to geological exploration permits us to single out and rank promising areas, and to provide a preliminary quantitative estimate of mineral reserves of both large and small areas.

\section{Hydrogeology and Engineering Geology}

Fundamental research in hydrogeology is aimed at revealing the laws governing the migration of ground water in the freewater exchange zone of the hydrosphere. This work contributes largely to the exploration for and estimation of the groundwater reserves, the prediction of water inflows into underground workings during mining, and the control of water-salt regimes on reclaimed lands (Kats and Shestakov, 1981). Work on the spatial variation in engineering properties of rocks assists hydrogeologists to define regional characteristics, to develop the theoretical basis for predicting exogenetic processes, and to construct maps showing the predicted development of geodynamic processes to the year 2000 (Artyshkov, 1982; Sergeyev, 1976-1978).

\section{Mineral Resources}

The U.S.S.R. possesses large reserves of oil and gas (see Meyerhoff, 1981, 1983 - Ed.), including one of the world's largest oil and gas provinces, that of West Siberia. This latter region has been rapidly developed, from an output of 200 tons of oil in 1964 to the present figures, which represent over $60 \%$ of the total volume of oil and $50 \%$ of the gas produced in the U.S.S.R. The largest oil and gas provinces within the Russian platform are represented by the VolgaUral, Timan-Pechora and Caspian provinces. Large gas fields have been explored in the Amu-Darya region of Central Asia, and considerable oil and gas potential is associated with the Lena-Tunguska, Yenisei-Laptev and Lena-Vilyui provinces of East Siberia.

The Soviet Union is rich in reserves of bituminous and brown coal (Anon, 1962-1978). The major Donbas basin provides one-third of the Soviet production of coal, almost half of which is of coking quality. The Kuznetsk basin of West Siberia has become the largest source of high-quality powergenerating and coking coals; coals from this basin are distinguished by their high quality and great variety in rank. The Kansk-Achinsk basin is unique in its large brown coal reserves and favourable mining conditions; the development of this basin is one of the most important energy goals of the

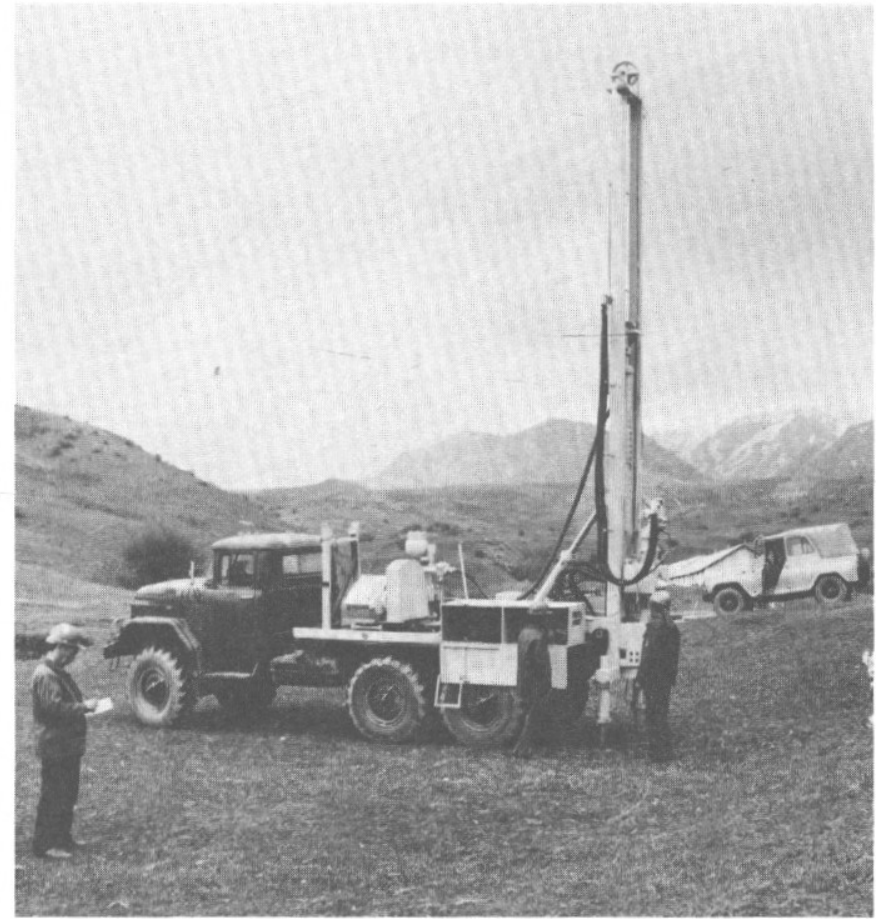

Figure 5: Drilling for groundwater in Central Asia.

U.S.S.R. Sizeable coal deposits have also been explored in the Pechora, Karaganda, Ekibastuz and South Yakutia basins, among others, and there are immense resources in the as yet poorly studied Tunguska and Lena basins of Siberia.

The supply of ferrous metals is well provided from mineral resources (Smirnov, 1974). Iron ore deposits of the Krivoi Rog basin in the Ukraine and of the Kursk Magnetic Anomaly area occupy leading positions both in identified reserves and production. Large iron deposits are also mined in the Urals and the Kola Peninsula, in Karelia, Kazakhstan, and West and East Siberia, and new districts are being explored in South Yakutia. The Soviet Union possesses considerable resources of manganese ores in the Ukraine, Georgia and central Kazakhstan, and chromium ores in northwest Kazakhstan.

Large reserves of non-ferrous metals have also been established. Copper deposits are being worked in Kazakhstan (cupriferous sandstones, Cu sulphide and $\mathrm{Cu}$ porphyry ores), Uzbekistan (Cu porphyry), the Urals (Cu sulphides), the area of the Baikal-Amur Railway (cupriferous sandstones) and together with $\mathrm{Ni}$ in the Norilsk district and the Kola Peninsula. $\mathrm{Pb}$ and $\mathrm{Zn}$ are mined in Rudnyi Altai and central Kazakhstan, Uzbekistan, Tadzhikistan, Transbaikalia, Azerbaijan and in the Krasnoyarsk region. Al comes from bauxites of the Urals, Timan, Kazakhstan, the Kursk Magnetic Anomaly area and the Arkhangelsk region as well as from nepheline-bearing rocks of the Kola Peninsula and West Siberia. There are also the alunite ores of Transcaucasia, W in the North Caucasus, Kazakhstan, Transbaikalia and Far East, Sn in the Far East and Kirgizia, and Mo in East Siberia, Kazakhstan and Armenia. The development of the diamond deposits of Yakutia represent a remarkable achievement (Anon, 1967).

Large reserves of raw fertilizer materials have been discovered in the world-famous apatite deposits of the Khibin group on the Kola Peninsula, in phosphorite deposits of Kazakhstan, central areas of the European part of the U.S.S.R. and Estonia, and in potash salts of the Perm area Byelorussia, Western Ukraine, Turkmenistan, and East Siberia. 
sediments were laid down under shallow-water to lacustrine conditions. This change in sedimentation probably reflects the start of the underthrusting described later.

The North Coast Basin is floored mainly by Pacific Plate crust as shown by upfaulted slivers of Early Tertiary island arc and oceanic voleanics, which are found sporadicallv throughout. The foredeep thus appears to have resulted from downbuckling of the oceanic crust during the compression that formed the Central Range.

\section{The Melanesian Orogeny: Pleistocene to Recent}

At some time after the elevation of the Central Range, the mechanism of crustal adjustment underwent a major change as the southwards overthrusting of the continental rocks ceased and the Pacific Plate began to underthrust the North Coast Basin. Evidence for the timing of the change is seanty, but it probably roughly coineides with the change of sedimentation in Early Pleistocene times mentioned above.

The major manifestation of this underthrusting is the Mamberamo Thrust Belt, a bewilderingly complex system nearly $400 \mathrm{~km}$ long by $100 \mathrm{~km}$ wide, of curved, anastamosing faults that cuts obliquely southeastwards from the coast in the northwest nearly to the Papua New Guinea border at the eastern end of the Irian Jaya Ophiolite Belt. The Mamberamo Thrust Belt is now the site of very intense seismic activity (Fig. 7), and focal plane solutions on some of the earthquakes indicate thrusting. The Pacific Plate is apparently actively underthrusting the region today.

A spectacular feature of the Thrust Belt is the pervasive intrusion of shale diapirs which make up most of the surface outerop of the $50 \mathrm{~km}$-wide medial zone (Williams et al., 1984). The surface manifestations of these diapirs can be puzzling for the field geologist, for the only coherent stratigraphy is found in the larger rafted fragments, which may be displaced many hundreds of metres vertically relative to neighbouring fragments. Impose the effects of regional underthrusting, and the elucidation of the geology becomes impossible. As an illustration, one large, almost horizontal slab of sediments over $800 \mathrm{~m}$ thick and from 4 to $5 \mathrm{~km}$ across, was mapped during earlier petroleum exploration as a normal succession, but abundant sedimentary features show conclusively that the whole slab is completely overturned (see also Fig. 8). As it abuts a gentle syncline of normal appearance one can understand the difficulties posed in working out the stratigraphy and structure.

The most common surface expression of the diapirs is a mass, generally kilometres across, of sealy clay (Fig. 9) containing chaotic and unsorted fragments of all sizes, from sand grains

\footnotetext{
Figure 8: Competent greywacke beds right "flapped" upwards (centre) by shale diapir (slumping material) making up the left third of the photo. Textural details of this diapir are seen in Figure 9.
}

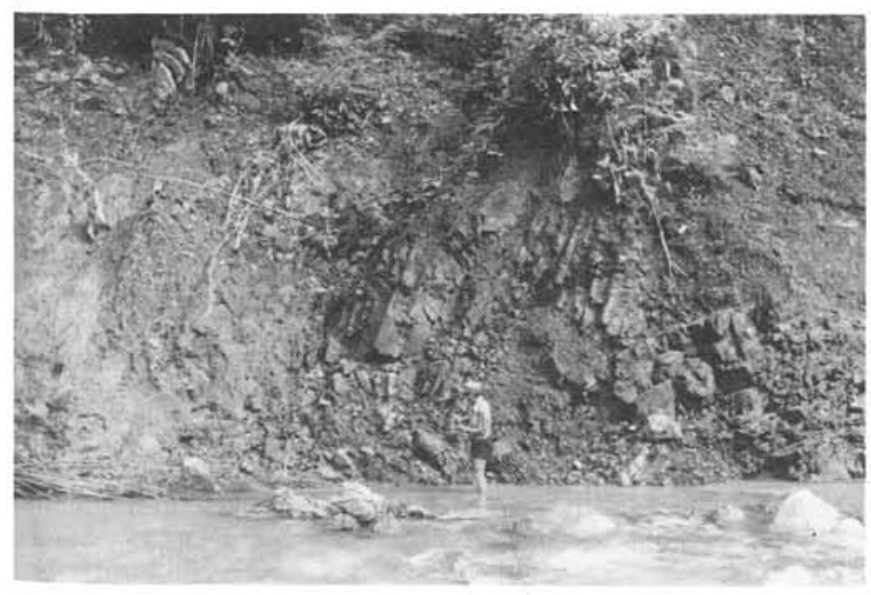

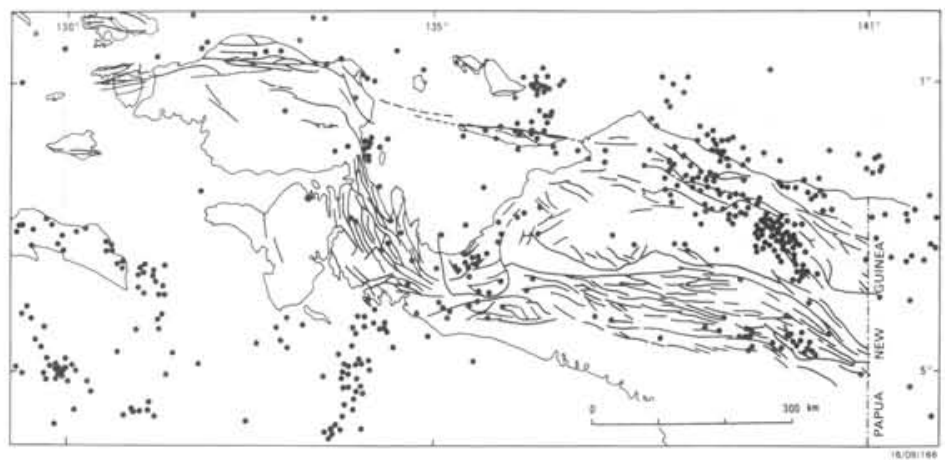

Figure 7: Seismicity of Irian Jaya. Epicenters for earthquakes to $34 \mathrm{~km}$ depth and with magnitude 44.99. Data to December 8, 1983, from the BMR earthquake file.

upwards. Many of the diapirs are still active and scaly clay can be seen doming recent river terraces and squeezing into stream beds like toothpaste. Awav from the streams the diapirs are characterized by ubiquitous muddy landslides involving the jungle cover, even in areas of low relief. The whole effect is one of disconcerting instability.

The other major manifestion is mud voleanoes of which there are many hundreds in the diapir belt, ranging from small mounds a few metres wide to substantial domes a kilometre or more across and up to $100 \mathrm{~m}$ high. The latter can be seen even on the LANDSAT imagery. The most impressive occurrence is near the centre of the Thrust Belt where coalescing mud volcanoes form a mass over $50 \mathrm{~km}$ across. Many of the mud voleanoes are located near major faults which have probably provided channelways for the dewatering of pressured shales at depth.

\section{Mechanism of Underthrusting}

As seen in Figure 4, the Mamberamo Thrust Belt forms the link between the Yapen Fault Zone to the west and the Bewani-Torricelli Fault System to the east, both of which are predominantly left-lateral strike-slip. It is apparent, therefore, that the Mamberamo structure must have a predominant thrust component, and that it must be almost entirely convergent in nature. This accords well with the field observations, though there is some room for divergence

Figure 9: Diapiric shale showing randomly contorted slickensides forming a "scaley clay." small polymict rafted rock fragments are shown. Some (bottom left) have been highly polished during transport.

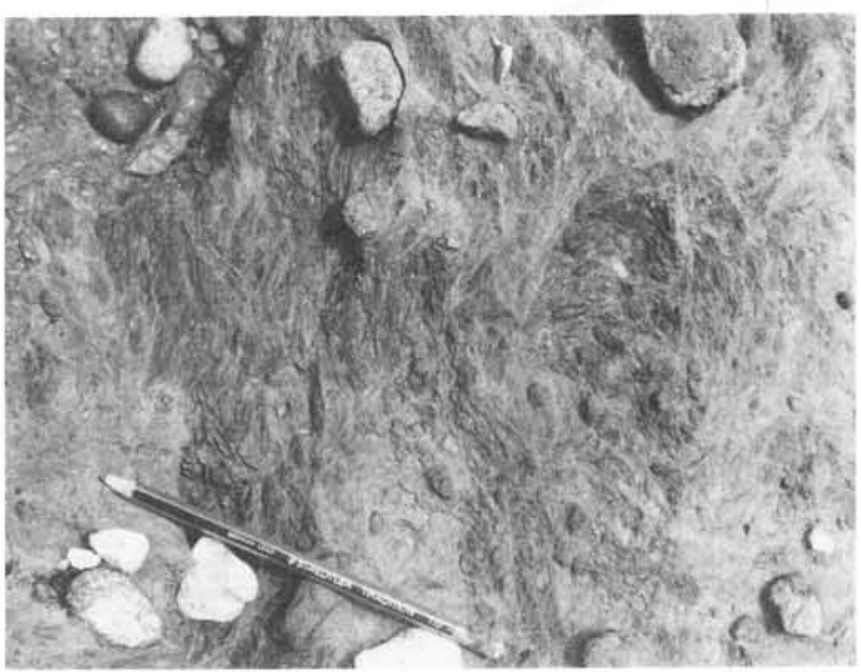




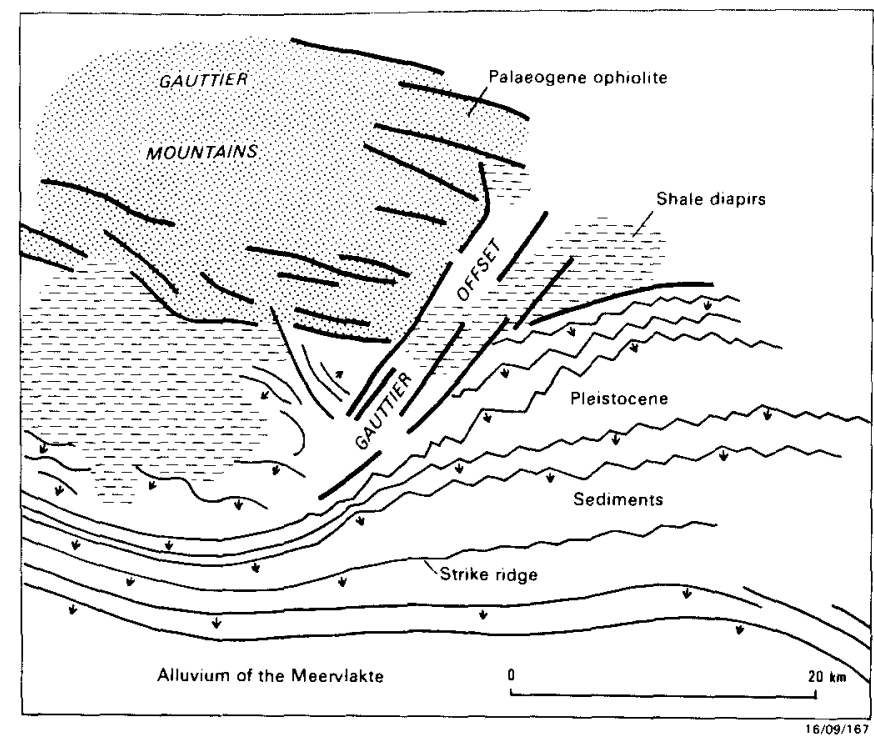

Figure 10: The Gauttier offset showing progressive left-lateral displacement of pleistocene sediments. For location see Figure 5.

from this simple picture because the seismicity of the region shows that a small proportion of the convergence is being taken up by other parts of the New Guinea Mobile Belt.

Nevertheless there is one more piece of evidence indicating that the convergence across the Mamberamo Thrust belt is close to the postulated direction of $S 55^{\circ} \mathrm{W}$. This is the presence of another fundamental structure, called here the Gauttier Off set.

\section{The Gauttier Offset}

The Gauttier Offset (Fig. 10) trends about $35^{\circ}$ southwest, and displaces the Mamberamo Thrust Belt left laterally by about $40 \mathrm{~km}$. The displacement has heen purely strike slip, so the structure is analogous to a transform fault and probably provides an accurate measure of the direction of maximum convergence.

The displacement is also shown by Pleistocene sediments that were laid down over the Offset while it was moving. Thus the older sediments have been displaced by progressively greater amounts up to a maximum of $20 \mathrm{~km}$, which is the displacement of the oldest beds preserved (Fig. 10).

The Gauttier Offset also displaces the Irian Jaya Ophiolite Belt by a similar amount but not the continental rocks of the Central Range. It appears, therefore, that the leftlateral displacement on the Offset has been accommodated by thrusting of the Pacific Plate rocks over the continental margin by about $40 \mathrm{~km}$.

It is worth noting that the great mass of coalescing mud volcanoes deseribed earlier is centred on the northeastern extension of the Gauttier Offset, which must have provided a major conduit for the dewatering of the shales.

Continental crust
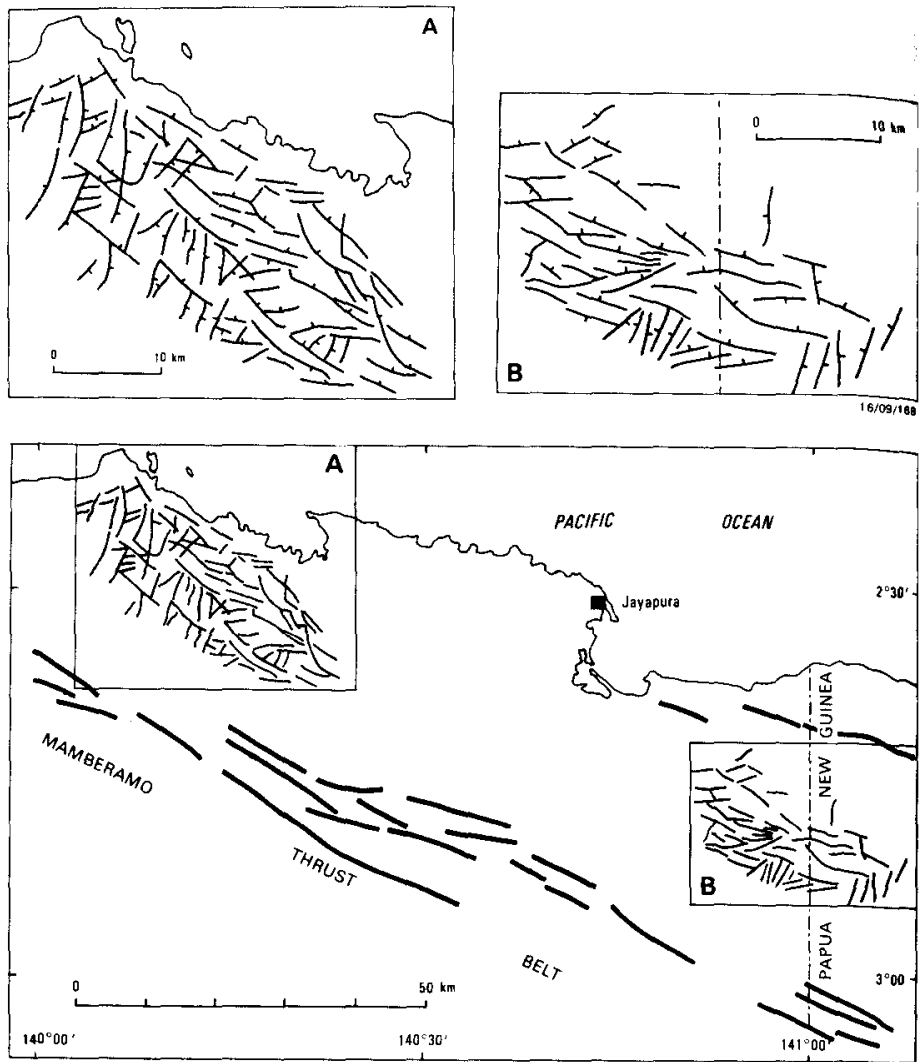

- Mojor fault

Normal fawt

Tick indicates downthrow side

Figure 11: Tensional faults exhibited by two large sheets of Middle Miocene Hollandia limestone. For location see Figure 5.

Figure 12: Diagrammatic cross section along line of section shown on Figure 5 to show the Post-Miocene evolution of the New Guinea Mobile Belt.
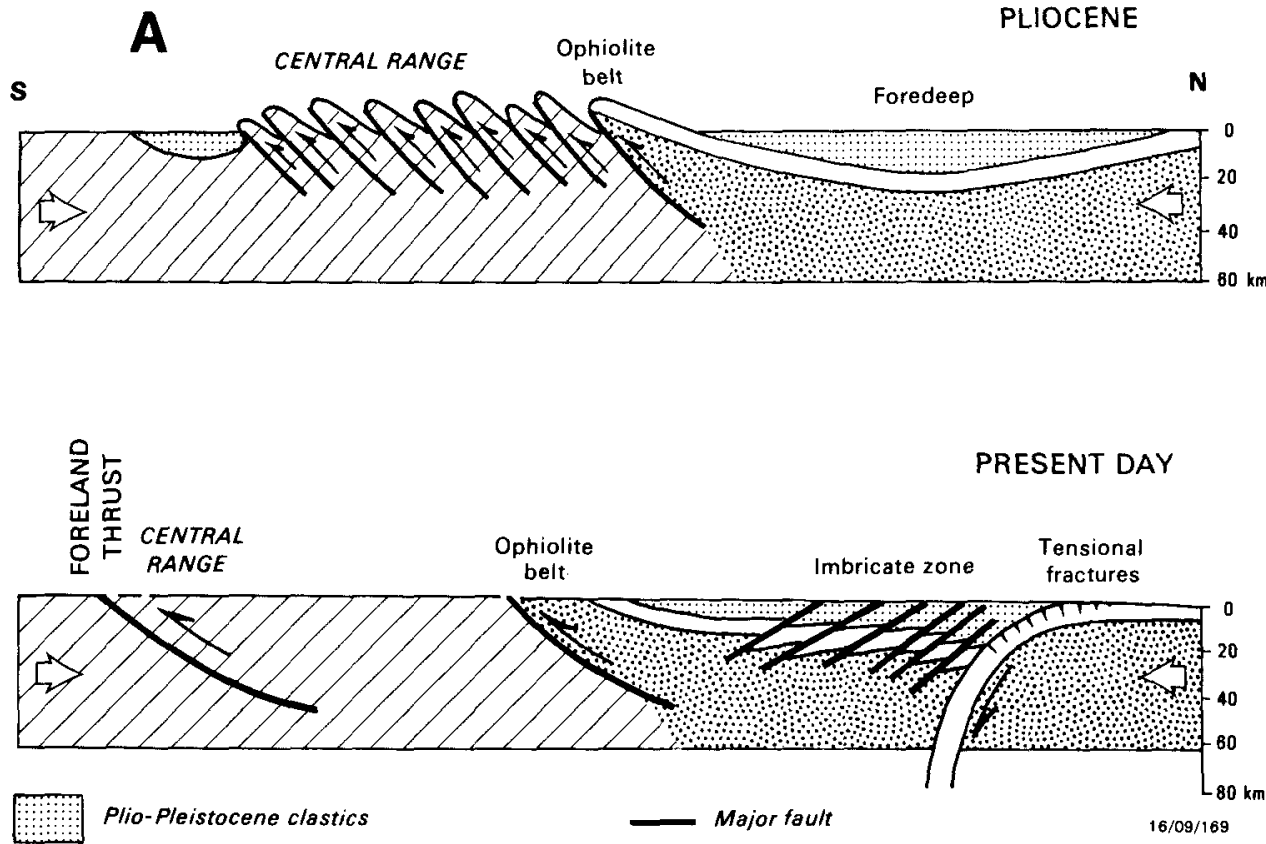

Oceanic crust and mant/e 


\section{Magnitude of Crustal Shortening}

The amount of crustal shortening that has taken place in eastern Irian Jaya since underthrusting started in the Middle Pleistocene is not known, but we have made rough estimates of the convergence accommodated by the major structures of the New Guinea Mobile Belt. These are as follows: overthrusting of the Ophiolite Belt $(40 \mathrm{~km})$, imbrication across the Mamberamo Thrust Belt $(30 \mathrm{~km})$, and thrusting on the Foreland Thrust $(10 \mathrm{~km})$. The combined figure of $80 \mathrm{~km}$ shortening probably does not represent the total involved because the earthquake hypocentres associated with the Mamberamo Thrust Belt occupy a zone that plunges steeply southwards to a depth of about $100 \mathrm{~km}$. This has lead $\mathrm{H}$. Letz (personal communication) to speculate that the Pacific Plate may be subducting along the northern margin of the Thrust Belt.

If this is indeed the case it would explain very neatly the large areas of tensional faulting on the southern margin of the Pacific Plate where the rocks are exposed northeast of the Mamberamo Thrust Belt around Jayapura and across the border in Papua New Guinea (Fig. 11). These are the only tensional structures mapped in the body of Irian Jaya, and they could have resulted from tensional stress where the Pacific lithosphere bends downwards into the subduction zone. Similar tensional features are known from the Pacific Ocean margin (Hilde 1983), but to our knowledge in no other region have they been recognized on land.

Assuming that the Pacific Plate is subducting along the northern coast of the body of Irian Jaya, then the Mamberamo Thrust Belt can be seen to be a zone of imbrication along the convex front of the subducting plate. Though the end product is similar to an accretionary wedge and includes a major scaly clay component (Williams et al., 1984), its origin is completely different from that usually ascribed to accretionary wedges. Here the sediments are autochthonous, being derived mainly from erosion of the orogenic belt to the south, and the sealy clays are formed, not by tectonic down-pushing, but rather by the upwards, buoyant, diapiric response.

If Pacific Plate crust is indeed down-going, it is apparent that the subduction is in its early stages, because nowhere in Irian Jaya is there recent igneous activity. The sinking slab, therefore, has not yet reached depths necessary for magma generation. The depth of the zone of earthquake foci indicates that up to $100 \mathrm{~km}$ of crust could have been subducted, giving a total crustal shortening since the beginning of the Middle Pleistocene of up to $180 \mathrm{~km}$.

\section{Summary}

In the Late Miocene and Pliocene, compression in eastern Irian Jaya resulting from convergence between the Australian and Pacific plates caused southwards overthrusting of the continental crustal rocks of the northern margin of the Australian continental block (Fig. 12A). This led to the formation of a thickened and uplifted wedge of continental crust that now forms the Central Range. Though there is no direct evidence, it seems likely that the Irian Jaya Ophiolite Belt was uplifted to its present elevation by overthrusting (obduction) of the Pacific Plate crust and mantle rocks.

Downbuckling of the lithosphere on both sides of the overthrust welt formed deep basins, especially in the north (F ig. 12B). In these accumulated great thicknesses of sediments derived from the eroding mountains. Subsequently, the overthrust welt resisted further deformation and during the Pleistocene the northern foredeep became the site of southwards underthrusting of Pacific Plate lithosphere. It is believed that the lithosphere has detached along the northern margin of the Mobile Belt and is now subducting at a steep angle.

Immediately south of the subducting lithosphere, stranded oceanic crust is being strongly imbricated along a zone of underthrusting. The Pliocene sediments involved in this underthrusting have been overpressured and are being buoyed to the surface as shale diapirs and mud voleanics. Some of the compressive stress is being transmitted across the northern margin of the continental block and is being relieved by southwards overthrusting along two fracture zones, one along the Ophiolite Belt and the other at the southern margin of the Mobile Belt.

\section{Acknowledgements}

This paper is based on data collected by members of the Irian Java Geological Mapping Project who contributed also in developing the ideas presented. Their help is gratefully acknowledged. Published with the permission of the Director, Geological Research and Development Centre, Bandung, Indonesia, and Director, Bureau of Mineral Resources, Geology and Geophysies, Canberra, Australia.

D. B. Dow has worked since 1955 with the Australian Bureau of Mineral Resources and has mapped widely in Australia and Papua New Guinea. He was Director of the Geological Survey of Ethiopia between 1968 and 1971, and Chief Geologist of the Geological Survey of Kenya between 1974 and 1977 . Since 1978 he has been the Australian Manager of the Irian Jaya Project (IAGMP, Jl. Cilaki 49, Bandung, Indonesia).

R. Sukamto is chief of the Geological Mapping Division of the Geological Research and Development Centre (Jl. Diponegoro 57, Bandung, Indonesia), and the Indonesian Project Manager of the Irian Jaya Project. He has been a field geologist of the Geological Research and Development Centre since 1958, and has been involved with field mapping in Java, Sulawesi, Banggai, Sula, Talaud and Halmahera.

\section{References}

American Association of Petroleum Geologists, 1981, Plate Tectonic Map of the Circum-Pacific Region. Blow, W.H., 1969. Late middle Eocene to Recent planktonic foraminiferal biostratigraphy. Proceedings of the ist International Conference on Planktonic Microfossils, 1967, Gieneva, Switzerland, v, 1, p. 199-422. Dow, D.B., 1977. A geological synthesis of Papua New Guinea. Australian Bureau of Mineral Resources, Geoloky Geophysies, no. 201. 41 p.

Dow, D.B, and Hartono, U., 1982. The nature of the erust underlying Cenderawasih (Geelvink) Bay Irian Jaya. Indonesia Petroleum Association, Proceedings 11 th Annual Convention.

Dow, D.B. and Sukamto, R., 1984. Western Irian Jaya: The end-product of oblique plate convergence in the lete Tertiary, Tectonophysices, v, ine, no, 1-2, p. 109-139.

Dozy, J.J., 1938. Eine gletscherwelt in Niederlandisch Neuguinea. Zeitschrift fur Gletscherkunde, v. 26, no. $1-2$, p. $45-51$.

Hamilton, W., 1979. Tectonies of the Indonesian Region, U.S. Geological Survey Professional Paper, 1078, $345 \mathrm{p}$.

Hermes, J.J.,
$(2), 0.81-97$,

Hilde, T.W.C. 1983. Sodinen Hilde, T.W.C., 1983.

Jacques, A.L. and Robinson, G.P., 1977. The continent/island are collision in northern Papua New Guinea. BMR Journal of Australian Geology and Geophysies, v. 2, no. 4, p. 289-303,

Minster, J.B. and Jordan, T.H., 1978. Present-day plate motions, Journal of Geophysical Researeh, v. 83, no. B11, D. 5331-5354.

Norviek, M.S., 1979. The tectonic history of the Banda Geological Society of London, 136 (part 5), p. 519-527. Pigram, C.J., Robinson, G.P. and Tobing, S.L., 1982. Late Cainozoic origin for the Bintuni Rasin and adjacent Lengguru Fold Belt, Irian Jaya. Indonesia Petroleum Association Proceedings 11th Annus

Pigram, C.J. and Panggsbean, H., 1983. Rifting of the northern margin of the Australian continent during the breakup of Gondwana, 6th Australian Geological Convention, Canberra, Abstraet.

Ripper, I.D., 1975. Seismicity and earthquake focal mechanisms in the New Guinea Solomon Islands region. Australian Society of Exploration Geophysicsts Bulletin, v, 6, no. 2-3, p. 80-81.

Robinson, G.A. and Ratman, N., 1978. The stratigraphic and tectonic development of the Manokwari area, Irian Jaya. BMR Journal of Australian Geology and Geophysies, v, 3, no, 2-3, p. 19-24.

Visser, W.A. and Hermes, J.J., 1962. Geological results of the exploration for ofl in Netherlands NeW Guinea. Koninklijk Nederlands Geologisch-Mijnbouwkundig Genootsehap, Verhandelingen, Geologische serie

Williams, P.R., Pigram, C.J. and Dow, D.B., 1984. Melange production and the importance of shale diapirism in aceretionary terrains, Nature, v. 309, No. 5964, p. 145-146. 